\title{
Stagnation in industry?
}

Werner Gries report from Bonn about statistics on research in Germany today

AcCording to a review presented by the federal government to the German parliament, research expenditure in the federal republic amounted to DM25,960 million in $1976,2.3 \%$ of the gross national product. The total number of staff employed in R\&D, some 303,500 , has been stagnating for three years; the number of persons employed in research in the industrial sector has actually declined. Expenditure for 1977 is estimated at DM27,300 million, up $5.3 \%$ on 1976.

The government's share of total research expenditure in Germany is about $51 \%$, industry's share about $48 \%$. Some $60 \%$ of research expenditure is effected through government grants in the industrial sector, where the state pays an average allowance of $20 \%$ of industry's own expenditure. This support amounted to DM3,000 million in 1976, of which DM1,200 million went to defence $R \& D$ and the rest to civilian $R \& D$. Of government expenditure on civilian $\mathrm{R} \& \mathrm{D}, \quad 72 \%$ is handled through the federal Ministry of Research and Technology.

In 1975, the latest year for which figures are available, 186,200 persons were employed in R\&D in industry. This represents a decline of $6.5 \%$ compared with the peak in 1971 of 200,000 employees, but the decrease was in the number of assistant staff and not of research workers themselves. The number of research workers rose by $8.8 \%$ over 1971-1975, and assistant staffs were considerably reduced. The decisive factor may have been the pressure of costs in the German economy. As possessors of technical knowledge, research workers were not dismissed, while the work of the assistants was increasingly done by highly trained research workers.

Industry's research expenditure is concentrated in a few firms, as evidenced by the fact that $96 \%$ of research expenditure is effected by firms which have more than a thousand employees. Government promotion of research in industry has also concentrated on those firms which have the largest research budgets. Only $6.3 \%$ of government research funds in recent years have been for the benefit of small and mediumsized firms. The promotion of research by fiscal means is at present of only minor importance in the industrial sector, because several tax concessions for research were stopped in 1975. The proportion of funds accruing to firms via fiscal promotion of research is about $2 \%$ of the total research expenditure financed by the firms themselves.

The distribution of research expenditure among the branches of German industry bears examination. Steel construction, mechanical engineering and the motor vehicle industry used $34 \%$ of the total for all firms. These industries also received $48 \%$ of government research money for industry. The number of research personnel in these industries declined in the years 197173 , however, from 62,100 to 54,300 .

The electrical engineering, precision engineering and optical industries used $30 \%$ of research expenditure by firms. They received, on average, government allowances of $15 \%$ of their own expenditure. Research staffs in these industries have increased slightly in recent years, but electrical engineering experienced a decline from about 53,900 in 1971 to 52,700 in 1973.

The third largest and most researchintensive branch of industry in Germany is the chemical, oil and plastics sector. Some $28 \%$ of firms' research expenditure is done in this branch of industry, and it receives only $2 \%$ of its research expenditure from the state. Research staffs in the chemical industry fell from a peak of 50,400 in 1971 to 47,400 in 1973 . The reduction was not in the number of research workers but in their assistant staffs.

Remaining branches of industry use only $7 \%$ of research expenditure by firms. But taken as a whole the figures indicate that stagnation in research expenditure has set in even in Germany. In the industrial sector there is a real decline in research expenditure and a reduction in personnel. It is a trend which can be observed in several other western industrial countries, except for Japan.

- The federal government will distribute DM436.3 million for projects in non-nuclear energy research in 1978, chieffy to build demonstration projects in coal refining, district heating and hot water supply from solar energy. Fundamental research will be supported in coal technology, energy conversion and the efficient use of energy.

Under a special economic programme, a number of prototype plants using new energy technology have been promoted, notably the use of heat pumps in public installations. The largest $(4.65 \mathrm{MW})$ gas heat pump in the world so far started working at Paderborn on 21 October 1977.
USSR

\section{Brezhnev's surprise}

Vera Rich reports on Mr Brezhnev's jubilee speech for the sixtieth anniversary of the October revolution

Mr BREZHNEV's jubilee speech followed traditional lines for the most part but contained two surprises. The most remarkable feature of his speech was the section on reducing the danger of nuclear war. In addition to the wellreported commitment to an eventual total ban on nuclear weapon tests-to include underground as well as atmospheric, outer-space and underwater tests-he stated that the Soviet Union was prepared to agree to a moratorium on peaceful nuclear explosions (PNE).

PNE forms an important part in the Soviet plans for diverting the Siberian rivers southward to irrigate the arid steppes of Central Asia. This diversion is not entirely dependent on PNE: for explosions below 10 megatons, conventional explosives are more cost-effective, except where difficult terrain poses special logistic problems. Nevertheless, a year ago the Soviet media began to comment extensively on the use of PNE in the project, and it was envisaged as a major mark of progress. Indeed, so anxious were the Soviet authorities to use PNE in the diversion project that they were even prepared to agree to on-site American inspection. Now, however, Mr Brezhnev is apparently willing to sacrifice the whole project as the price of a test-ban treaty, and to revert to more conventional means of canal-building.

The other major surprise was the figures for this year's harvest. In spite of fervent denials by the foreign services of Moscow radio, Western experts had expected a shortfall of some $8 \mathrm{mil}$ lion tonnes. Although $\mathrm{Mr}$ Brezhnev made no reference to shortfall, the total yield of 194 million tonnes means that the shortfall from the target is no less than 19 million tonnes. Although the weather must be largely held responsible, it is not surprising that the future plans for agriculture stress the intensive development of agriculture.

Other present and future plans outlined in the speech include the opening up of Siberia by the Baikal-Amur railway, the new plans for developing the non-black earth zone, and "the discovery of new sources of energy and substitutes for many types of natural resources, the technical re-equipment of the economy to reduce manual and especially arduous labour to a minimum, the boosting of agriculture, the combating of disease, and the prolongation of the human life-span". 